\title{
Experimental Study on Sansevieria Cylindrica Paver Blocks
}

\author{
M. Vijayakumar, M. Athipathy, M. Clement, P. Krishnakumar
}

\begin{abstract}
Concrete paver blocks in road pavement are used in the parking, hill road construction for soil strength lower areas. As per Indian standard, interlocking concrete paver blocks are used with M 35 grade concrete. This paper deals combination of sansevieria cylindrica fiber with normal concrete for making of new paver block. Here fibers are added in the proportions of $0.25 \%$ to $1.75 \%$ in the volume of cement mortar. The compressive strength was determined 28 days. The compressive strength of $0.75 \%$ sansevieria cylindrica fiber mix having more strength. While increasing percentage of fiber value the concrete strength is reduced.
\end{abstract}

Keywords: Fiber, Sansevieria cylindrical fiber, Paver blocks

\section{INTRODUCTION}

The natural fibers have low cost, easily available and give more adequate strength, durability for achieving more strength to making eco friendly concrete. Example of natural fibers are banana, hemp jute palm have been studied in various research activity. Cylindrica fiber is one such plant based leaf fiber which has not been explored to greater extent by the research fraternity. Solid unreinforced pre casted paver blocks are aesthetically attractive, functional and cost effective if they are correctly manufactured and placed. Interlocking concrete pavement are special dry mix precast concrete and it is used in parking areas, slope regions, hill roads, pedestrian foot path and temporary road construction.. These types of fiber are mixed with concrete for increasing strength and more life type. This new type paver block gives more durability and good aesthetic view. This type of paver blocks are also used in heavy traffic areas to carrying heavy loads. Fiber paver block is having more tensile strength and crack formation is reduced.

\section{METHODOLOGY}

Investigation and collection of raw materials

$>$ Testing of material

$>$ Cement, coarse aggregate, Fine aggregate, water

Revised Manuscript Received on August 15, 2020.

* Correspondence Author

Mr. M. Vijayakumar*, Assistant Professor, Department of Civil Engineering, Rathinam Technical Campus, Coimbatore, Tamilnadu, India.

Athipathy M, Assistant Professor, Department of Civil Engineering, Rathinam Technical Campus, Coimbatore, India.

Mr. M. Clement, Assistant Professor, Department of Civil Engineering Rathinam Technical Campus, Coimbatore, Tamilnadu, India.

Dr. P. Krishnakumar, Associate Professor and Head, Department of Civil Engineering, Rathinam Technical Campus, Coimbatore, Tamilnadu, India.

(C) The Authors. Published by Blue Eyes Intelligence Engineering and Sciences Publication (BEIESP). This is an open access article under the CC BY-NC-ND license (http://creativecommons.org/licenses/by-nc-nd/4.0/)

\author{
$>$ M35 grade of concrete \\ $>$ Natural fibre material-Test -Properties of material \\ $>$ Casting of concrete \\ $>$ Curing of concrete \\ $>$ Testing on concrete
}

\section{MATERIALS FOR MAKING PAVER BLOCK}

\section{A. Sansevieria Cylindrica}

This fiber is called as African spear or spear cylindrica. It have striped, elongated smooth greenish-gray leaves. They having $3 \mathrm{~cm}$ in diameter and grow up to $2 \mathrm{~m}$ above ground. It grows fan shaped, with its stiff leaves growing from a base. The elongation of fiber is $3.6 \%$. It has a length of $117 \mathrm{~cm}$. The fineness of this fiber is 9.0 .

\section{B. Cement}

Ordinary Portland cement of 53- grade with 32\% consistency used.

\section{Coarse aggregate}

Aggregate is retained on $4.75 \mathrm{~mm}$ IS sieve is termed as coarse aggregate. Here $20 \mathrm{~mm}$ size irregular crushed aggregate is used.

\section{Fine aggregate or sand}

In this project $\mathrm{M}$ sand is used. M-sand have specific gravity of 2.65 . The bulk density of sand is $1440 \mathrm{~kg} / \mathrm{m}^{3}$.

\section{E. Water}

Portable water is used, pH value between 6-7.

\section{F. Chemical Admixtures}

For improving workability sp 420 conplast chemical admixtures is used.

\section{G. Sansevieria fiber \\ Aspect ratio $=$ length of fiber/ diameter of fiber $=0.1 / 0.0002=50$}

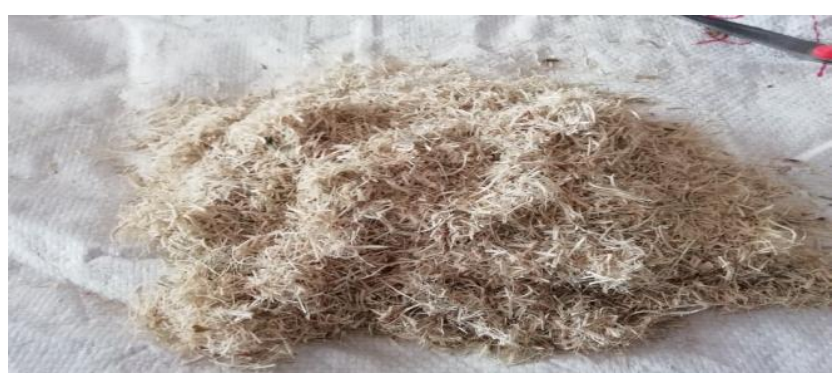

Fig 1. Sansevieria fiber

Published By:

Blue Eyes Intelligence Engineering and Sciences Publication

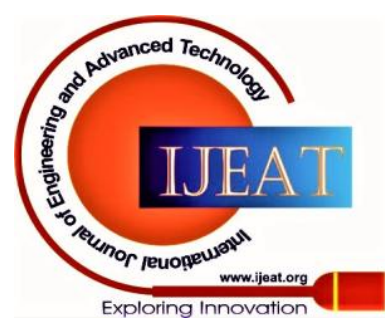




\section{Experimental Study on Sansevieria Cylindrica Paver Blocks}

\section{PHYSICAL PROPERTIES OF MATERIALS}

Cement: As per IS:8112, OPC of 53 grade cement is used.

Table- I: Property of cement

\begin{tabular}{|l|l|l|}
\hline S.No & \multicolumn{2}{|c|}{ Properties } \\
\hline 1 & Consistency test & $33 \%$ \\
\hline 2 & Fineness modulus & $10 \%$ \\
\hline \multirow{3}{*}{3} & $\begin{array}{l}\text { Setting time } \\
\text { Initial }\end{array}$ & $\begin{array}{l}30 \\
\text { minutes } \\
570 \\
\text { minutes }\end{array}$ \\
\hline
\end{tabular}

Coarse aggregate: Based on IS:383 locally available coarse aggregate of nominal size $20 \mathrm{~mm}$ is used.

Table- II: Property of Coarse aggregate

\begin{tabular}{|l|l|l|}
\hline \multicolumn{1}{|c|}{ S.No } & \multicolumn{2}{|c|}{ Properties } \\
\hline 1 & Sieve analysis & $3.44 \%$ \\
\hline 2 & Aggregate impact value & $19.87 \%$ \\
\hline
\end{tabular}

Fine aggregate: Based on IS:183 - M Sand

Table- III: Property of M sand

\begin{tabular}{|l|l|l|}
\hline S.No & \multicolumn{2}{|c|}{ Properties } \\
\hline 1 & Specific gravity & $2.65 \%$ \\
\hline 2 & Sieve analysis & 2.58 \\
\hline
\end{tabular}

Impact test value of coarse aggregate is $19.87 \%$, and have fineness modulus of CA is $3.44 \%$.

\section{MIX DESIGN}

M 35 grade concrete with $0.25 \%-1.75 \%$ fiber were used.

Area of paver block mould is $0.5 \mathrm{sq} . \mathrm{ft}$.

Cement: $350 \mathrm{~kg} / \mathrm{m}^{3}$

M- Sand: $8664 \mathrm{Kg} / \mathrm{m}^{3}$

Coarse aggregate: $1111 \mathrm{~kg} / \mathrm{m}^{3}$

Water: $140 \mathrm{~kg} / \mathrm{m}^{3}$

Chemical admixture: $7 \mathrm{~kg} / \mathrm{m}^{3}$

W/C: 0.4

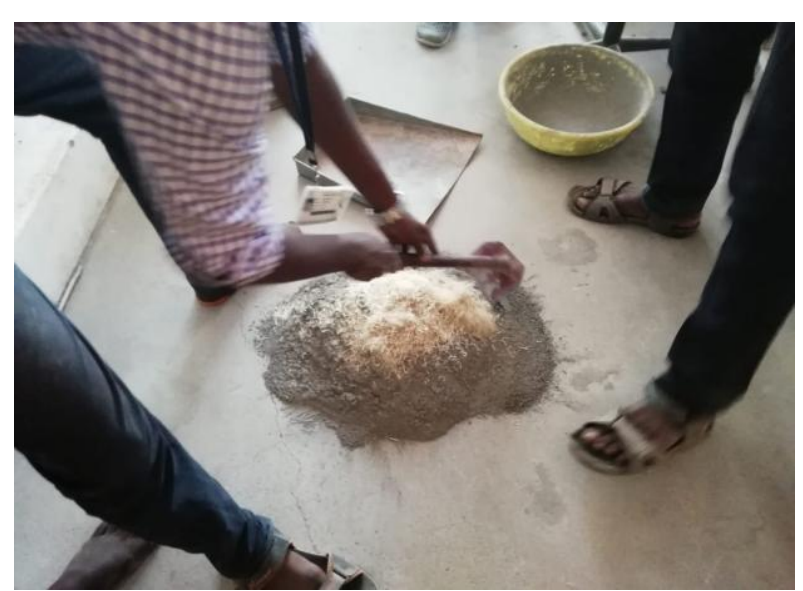

Fig 2. Concrete Mixing

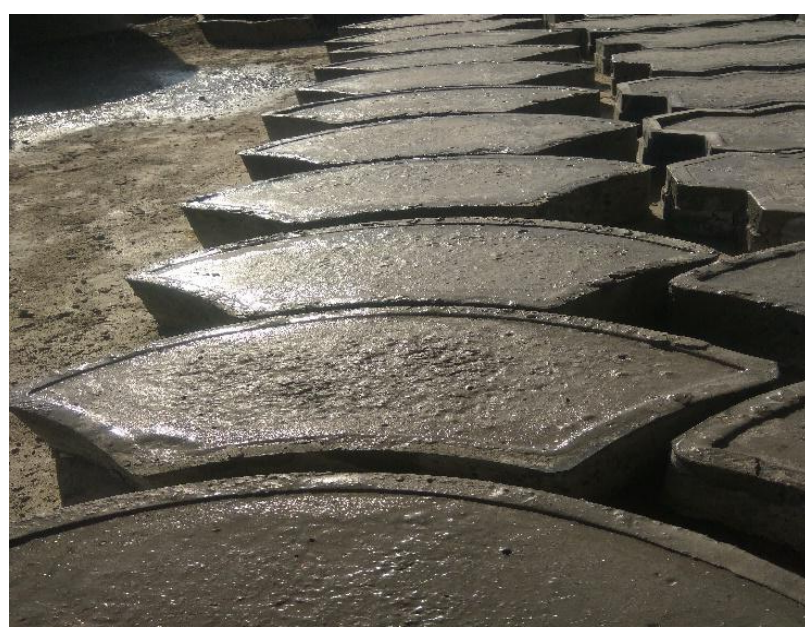

Fig 3. Paver block mould

\section{COMPRESSIVE STRENGTH OF PAVER BLOCK}

The test is performed after 28 days curing. The sample paver blocks are prepared about 24 nos.

\section{A. Test Procedure}

Paver blocks are remolded and kept 24hours normal drying and weight is taken.

The adjustment was made in compression test machine with $140 \mathrm{~kg} / \mathrm{m}^{2}$ load.

After loading, failure and crack patterns of different paver blocks were observed and maximum resisting load is calculated.

\section{TEST RESULTS}

Table- IV: Compressive strength of Paver block- 28 days

\begin{tabular}{|l|c|c|c|}
\hline S.No & Mix & \% of fiber & Strength in MPa \\
\hline 1 & M1 & 0 & 34.58 \\
\hline 2 & M2 & 0.25 & 36.25 \\
\hline 3 & M3 & 0.5 & 37.78 \\
\hline 4 & M4 & 0.75 & 30.45 \\
\hline 5 & M5 & 1.00 & 28.12 \\
\hline 6 & M6 & 1.25 & 25.75 \\
\hline 7 & M7 & 1.50 & 24.40 \\
\hline 8 & M8 & 1.75 & 23.65 \\
\hline
\end{tabular}

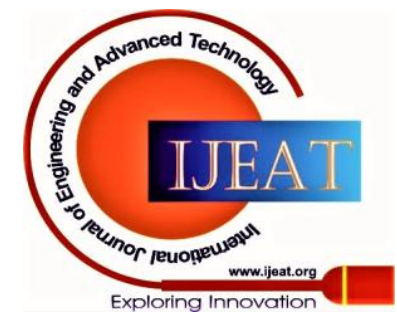


VIII. CONCLUSION

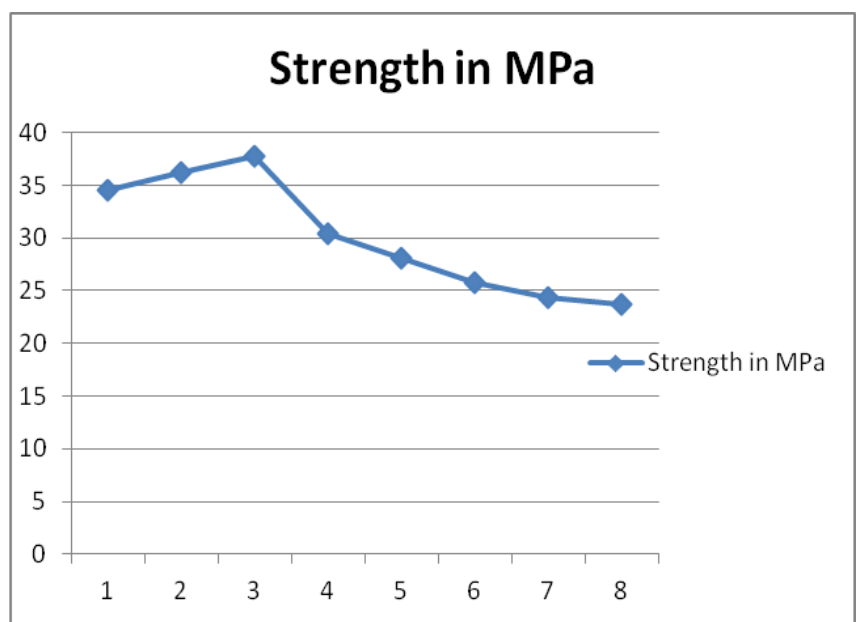

Fig 3. Compresssive strength of Paver block

- As per above test result, the compressive strength of paver block was found.

- The optimum mix is M3, because after this mix the strength of concrete will be reduced.

- The strength of concrete is decreased due to be increasing the percentage of fiber.

- Using cylindrical fiber the compressive strength of paver block increased up to $2 \%$.

- Based on above results, this paver block is suitable for road construction.

\section{REFERENCES}

1. G.Navya, J.Venkateshwara Rao "Experimental investigation on properties of concrete paver block with the inclusion of natural fibers" International Journal of Engineering Research and Application volume 4 (2014).

2. M.Achitra , R.Ambika Rajasree "Recycled plastic and coconut fiber used in concrete paver block".

3. IS-10262 (2009): concrete mix design proportioning: by Bureau of Indian Standards.

4. M.S.Shetty S.Chand, "Concrete Technology Theory and Pratice”.

\section{AUTHORS PROFILE}

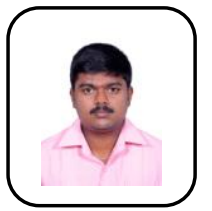

Mr. M. Vijayakumar is working as Assistant Professor in the Department of Civil Engineering at Rathinam Technical Campus, Coimbatore, Tamilnadu, India. He has completed his B.E in Civil Engineering and Master degree in Structural Engineering under Anna University, Chennai. I know BIM software AutoCAD, Revit architecture and STADD pro softwares. I have Handled Structural Analysis subject, Water Resource and Irrigation Engineering, Strength of materials, Concrete technology and Mechanics of structures. I have completed online course on Mechanics of Materials I, Maintenance and repair of concrete structures, Materials science: 10 things every engineer, and Mechanics of Materials - III - Beam Bending. I have doing consultant and research work in building materials and concrete.

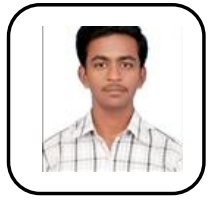

Athipathy M completed B.E Civil Engineering at Sona College of Technology, Salem, an Autonomous Institution affiliated to Anna University and M.E Construction Management at Coimbatore Institute of Technology, Coimbatore, a Government - Aided Autonomous Institution affiliated to Anna University. He is presently working as an Assistant professor in the Department of Civil Engineering, Rathinam Technical Campus, Coimbatore. He has 2 years of teaching experience and published about three International Journals in the field of Soil Stabilization Techniques and Concrete Technology. His areas of Interest are Construction Planning and Scheduling using Project Management Software's Primavera and Microsoft Project and Advanced Construction Materials, Techniques and Practices.

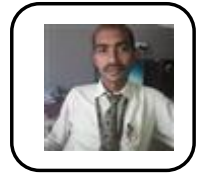

Mr. M. Clement is working as an Assistant Professor in the Department of Civil Engineering at Rathinam Technical Campus, Coimbatore, Tamilnadu, India. His highest qualification is M.E., Construction Engineering and Technology. He has more than 15 years on experience in the industry both India and abroad. He has about 5 years of experience in teaching Civil Engineering. He was actively involved in the testing of Highway materials for a period of about 5years. His core area of interest is Design and Drafting of Plumbing and Fire- fighting Systems for Multi storeyed buildings. His areas of interest are Construction materials testing, Concrete technology etc.

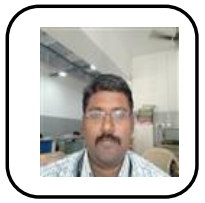

Dr. P. Krishnakumar is working as an Associate Professor and Head in the Department of Civil Engineering at Rathinam Technical Campus, Coimbatore, Tamilnadu, India. He has more than 8 years of research experience and has published many research papers in the area of Carbon Sequestration. He has over 8 years of experience in teaching Civil Engineering subjects .His areas of expertise lies in Remote Sensing, GIS, Satellite imagery, Water Supply and Waste water Engineering. He is actively involved in providing consultancy services to industries in the area of waste water treatment services and was instrumental in the designing and successful operation of a waste water treatment facility for the campus.

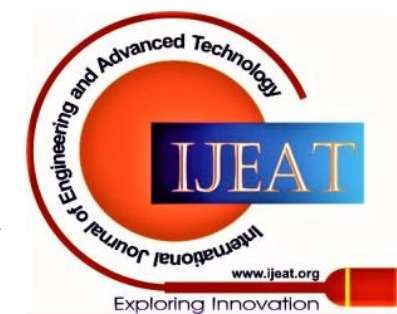

